\title{
Hubungan Kadar Seng Plasma dengan Derajat Penyakit Pneumonia
}

\author{
Paramita Diah Winarni, ${ }^{1}$ Dedi Rachmadi, ${ }^{2}$ Nanan Sekarwana ${ }^{2}$ \\ ${ }^{1}$ Rumah Sakit MH. Thamrin Purwakarta, ${ }^{2}$ Departemen Ilmu Kesehatan Anak Fakultas Kedokteran \\ Universitas Padjadjaran-Rumah Sakit Dr. Hasan Sadikin Bandung
}

\begin{abstract}
Abstrak
Pneumonia merupakan masalah kesehatan utama anak di dunia dan sebagai penyebab terbanyak morbiditas dan mortalitas anak di negara berkembang. Anak dengan defisiensi mikronutrien termasuk seng berisiko tinggi terjadi pneumonia, karena gangguan sistem imun. Penelitian ini bertujuan mengetahui hubungan kadar seng plasma dengan pneumonia, pneumonia berat, dan sangat berat pada anak usia 2-59 bulan. Penelitian observasi analitik dengan rancangan potong lintang dilakukan bulan Agustus sampai November 2009 di Departemen Ilmu Kesehatan Anak RS Dr. Hasan Sadikin Bandung, RS Ujung Berung, dan RS Cibabat. Subjek harus memenuhi kriteria diagnosis klinis pneumonia menurut World Health Organization (WHO) Indonesia dan berusia 2-59 bulan. Pengambilan sampel darah untuk pemeriksaan kadar seng plasma dilakukan saat penderita datang. Analisis data menggunakan uji eksak Fisher dan untuk melihat hubungan kadar seng plasma dengan derajat pneumonia menggunakan uji Mann-Whitney. Dari total 42 subjek yang memenuhi kriteria inklusi, didapatkan $1(2 \%)$ anak pneumonia, 32 $(76 \%)$ pneumonia berat, dan $9(22 \%)$ pneumonia sangat berat. Terdapat perbedaan bermakna $(\mathrm{p}=0,032) \mathrm{kadar}$ seng plasma antara kelompok pneumonia berat dan sangat berat dengan median 96,685 $\mu \mathrm{g} / \mathrm{dL}(57,32-195,66 \mu \mathrm{g} /$ dL) untuk penumoia berat dan $80,240 \mu \mathrm{g} / \mathrm{dL}(63,01-111,84 \mu \mathrm{g} / \mathrm{dL})$ untuk pneumonia sangat berat. Penelitian ini menunjukkan bahwa bahwa kadar seng plasma memiliki hubungan dengan pneumonia berat dan sangat berat pada anak usia 2-59 bulan. [MKB. 2012;44(4):213-17].
\end{abstract}

Kata kunci: Pneumonia, seng plasma, sistem imun

\section{Association Plasma Zinc Level with Severity of Pneumonia}

\begin{abstract}
Pneumonia is a major health problem affecting children all over the world and remains a major cause of childhood morbidity and mortality in developing countries. Children with micronutrients deficiency including zinc, which might cause immune system disorder, have higher risk to have pneumonia. The aim of this study was to investigate the association between plasma zinc level and pneumonia, severe, and very severe pneumonia in children aged 2-59 months. This observational analytic with cross-sectional study was performed at the Pediatric Department of Dr. Hasan Sadikin General Hospital, Ujung Berung Hospital and Cibabat Hospital, in August to November 2009. Subjects of this study were 2-59-month-old children who meet the WHO Indonesian classification for pneumonia. Blood samples for plasma zinc examination were collected on admission. Data were analysed using exact Fisher and Mann-Whitney test for the association between plasma zinc level and severity of pneumonia. A total of 42 subjects were enrolled, $1(2 \%)$ child were classified as having pneumonia, $32(76 \%)$ children with severe, and 9 $(22 \%)$ with very severe pneumonia. There were significant differences $(p=0.032)$ in plasma zinc levels between severe and very severe pneumonia with a median of $96.685 \mu \mathrm{g} / \mathrm{dL}(57.32-195.66 \mu \mathrm{g} / \mathrm{dL})$ for severe pneumonia and $80.240 \mu \mathrm{g} / \mathrm{dL}(63.0-111.84 \mu \mathrm{g} / \mathrm{dL})$ for very severe pneumonia. This study shows an association between plasma zinc levels and severe and very severe pneumonia in children aged 2-59 months. [MKB. 2012;44(4):213-17].
\end{abstract}

Key words: Pneumonia, plasma zinc, immune system

Korespondensi: Paramita Diah Winarni, dr., Sp.A, M.Kes, Rumah Sakit MH. Thamrin Purwakarta, jalan Raya Bungursari 36 Purwakarta,e-mail paramitadw@yahoo.com 


\section{Pendahuluan}

Di negara berkembang setiap tahun $>150$ juta episode pneumonia terjadi pada anak di bawah usia lima tahun (balita). ${ }^{1}$ Di Indonesia pneumonia merupakan penyebab terbesar kematian bayi dan balita. $^{2}$

Berdasarkan kriteria WHO Indonesia derajat penyakit pneumonia pada usia $2-59$ bulan dibagi menjadi pneumonia sangat berat, dan berat, pneumonia, serta bukan pneumonia. ${ }^{3}$

Terdapat kaitan yang erat integritas sistem imun dengan status seng seseorang. Anak dengan defisiensi mikronutrien termasuk seng berisiko tinggi terjadi pneumonia, karena gangguan sistem imun. ${ }^{4,5}$ Berdasarkan penelitian di Vietnam ${ }^{6}$ dan Nigeria Utara $^{7}$ pada anak malnutrisi ditemukan hubungan antara rendahnya asupan protein dan defisiensi seng. Antibiotik golongan kuinolon dan tetrasiklin menghambat penyerapan seng dalam saluran cerna. ${ }^{8,9}$

Pada anak Banglades berstatus gizi baik dengan infeksi saluran napas bawah akut, kadar seng plasma dan rambut signifikan lebih rendah. ${ }^{10} \mathrm{Di}$ India Utara anak yang dirawat karena pneumonia berat, memiliki kadar seng plasma lebih rendah dibandingkan dengan kontrol. ${ }^{11}$

Penelitian hubungan antara kadar seng plasma dan derajat pneumonia berdasarkan kriteria WHO Indonesia pada anak usia 2-59 bulan belum pernah dilakukan. Bayi 0-2 bulan dengan gejala pneumonia sulit dibedakan dari sepsis dan meningitis, serta tatalaksana dan klasifikasi, kuman penyebab yang berbeda. ${ }^{12}$ Bukan pneumonia atau batuk adalah infeksi saluran napas atas, sehingga tidak masuk dalam penelitian. ${ }^{3}$ Berdasarkan alasan di atas, dilakukan penelitian untuk mengetahui hubungan kadar seng plasma dengan pneumonia, pneumonia berat, dan sangat berat menurut WHO Indonesia pada anak usia 2-59 bulan.

\section{Metode}

Metode penelitian yang dipergunakan adalah observasional analitik dengan rancangan potong lintang dan pengambilan sampel secara consecutive sampling. Subjek penelitian adalah anak yang berobat ke Poliklinik Rawat Jalan atau Instalasi Gawat Darurat Departemen Ilmu Kesehatan Anak RS Dr. Hasan Sadikin Bandung, RS Ujung Berung dan RS Cibabat, mulai Agustus hingga November 2009 yang memenuhi kriteria klinis pneumonia menurut WHO Indonesia, dan berusia 2-59 bulan. Kriteria eksklusi adalah subjek berstatus gizi buruk atau lebih, menderita penyakit selain pneumonia, atau memiliki penyakit paru atau jantung bawaan. Penelitian ini telah mendapat persetujuan Komite
Etik Penelitian Kesehatan Fakultas Kedokteran Universitas Padjadjaran/RS Dr. Hasan Sadikin Bandung.

Penghitungan sampel penelitian dilakukan dengan menggunakan $\rho=0,4 ; \alpha=0,05$; hipotesis uji dua arah, taraf kepercayaan 95\% dan power test $80 \%$, berdasarkan tabel distribusi normal standar taraf kemaknaan dan power test yang dipilih, didapatkan $n \geq 47$. Subjek yang memenuhi kriteria penelitian dilakukan anamnesis, pemeriksaan fisis, dan pengambilan darah vena sebanyak $5 \mathrm{~mL}$ untuk pemeriksaan kadar seng plasma. Informasi pemakaian antibiotik diperoleh dari anamnesis. Penilaian status gizi dilakukan berdasarkan WHO Child Growth Standard 2005.

Analisis statistik yang dipergunakan adalah uji chi-kuadrat, tetapi bila sel mempunyai nilai expected kurang dari 5 maka digunakan uji eksak Fisher. Untuk uji hipotesis digunakan uji t tidak berpasangan bila distribusi data normal dan uji Mann Whitney bila distribusi data tidak normal. Penghitungan statistik dilakukan dengan piranti lunak SPSS versi 15.0 for Windows tahun 2005, SPSS Inc, Chicago-Illinois, USA.

\section{Hasil}

Selama bulan Agustus-November 2009, diperoleh 42 anak yang memenuhi kriteria penelitian, yang datang ke poliklinik dan UGD Departemen Ilmu Kesehatan Anak RS Dr. Hasan Sadikin Bandung, RS Ujung Berung, dan RS Cibabat.

Berdasarkan kriteria pneumonia menurut WHO Indonesia, didapatkan pneumonia (P) sebanyak satu (2\%) anak, pneumonia berat (PB) $32(76 \%)$, dan pneumonia sangat berat (PSB) sembilan (22\%) anak. Subjek pneumonia hanya berjumlah satu anak sehingga tidak dilakukan analisis. Karakteristik umum subjek penelitian dapat dilihat pada Tabel 1 .

Sebagian besar populasi penelitian ini adalah anak berstatus gizi baik, yaitu 37 (90\%) orang dan sebanyak $21(51 \%)$ orang telah mendapat antibiotik sebelumnya (Tabel 2).

Dari hasil pemeriksaan tersebut, didapatkan perbedaan kadar seng plasma bermakna $(p=0,032)$ antara pneumonia berat dan sangat berat. Subjek yang memiliki kadar seng plasma $<80 \mu \mathrm{g} / \mathrm{dL}$ sebanyak 11 (26\%) anak (Tabel 3).

\section{Pembahasan}

Dari 42 anak yang memenuhi kriteria penelitian didapatkan sebagian besar subjek berjenis kelamin laki-laki (66\%) dan berusia $<12$ bulan (63\%). Hal ini sesuai dengan penelitian Brooks dkk., ${ }^{1}$ Bose dkk., ${ }^{13}$ dan Scott ${ }^{14}$ bahwa anak laki- 
Tabel 1 Karakteristik Umum Subjek Penelitian

\begin{tabular}{|c|c|c|c|c|}
\hline \multirow[b]{2}{*}{ Variabel } & \multicolumn{2}{|c|}{ Derajat Penyakit Pneumonia } & \multirow[b]{2}{*}{ Jumlah } & \multirow[b]{2}{*}{$\mathbf{p}$} \\
\hline & $\begin{array}{c}\text { PB } \\
(n=32)\end{array}$ & $\begin{array}{l}\text { PSB } \\
(n=9)\end{array}$ & & \\
\hline \multicolumn{5}{|l|}{ Jenis kelamin } \\
\hline Laki-laki & 21 & 6 & $27(66 \%)$ & 1,00 \\
\hline Perempuan & 11 & 3 & $14(34 \%)$ & \\
\hline \multicolumn{5}{|l|}{ Usia (bulan) } \\
\hline $2-11$ & 18 & 8 & $26(63 \%)$ & 0,119 \\
\hline $12-59$ & 14 & 1 & $15(37 \%)$ & \\
\hline
\end{tabular}

Tabel 2 Hubungan Status Gizi dan Pemakaian Antibiotik dengan Derajat Penyakit Pneumonia

\begin{tabular}{|c|c|c|c|c|}
\hline \multirow{3}{*}{ Variabel } & \multicolumn{2}{|c|}{ Derajat Penyakit Pneumonia } & \multirow{3}{*}{ Jumlah } & \multirow{3}{*}{$\mathbf{p}$} \\
\hline & PB & PSB & & \\
\hline & $(n=32)$ & $(n=9)$ & & \\
\hline \multicolumn{5}{|l|}{ Status gizi } \\
\hline Baik & 28 & 9 & $37(90 \%)$ & 0,559 \\
\hline Kurang & 4 & & $4(10 \%)$ & \\
\hline \multicolumn{5}{|l|}{ Antibiotik } \\
\hline Ya & 16 & 5 & $21(51 \%)$ & 1,00 \\
\hline Tidak & 16 & 4 & $20(49 \%)$ & \\
\hline
\end{tabular}

Keterangan: $\mathrm{PB}=$ pneumonia berat, $\mathrm{PSB}=$ pneumonia sangat berat

laki dan usia $<12$ bulan lebih berisiko terjadi pneumonia. Data karakteristik umum penelitian ini tidak didapatkan perbedaan statistik yang bermakna $(p>0,05)$ variabel jenis kelamin dan usia dengan kelompok pneumonia. Penelitian Khan dkk. ${ }^{15}$ memiliki hasil yang serupa, hal ini mungkin disebabkan subjek yang diteliti berada pada satu kelompok usia, yaitu 2-59 bulan yang memperlihatkan gejala klinis, klasifikasi, kuman penyebab, dan tatalaksana yang sama. ${ }^{16}$

Pada penelitian ini status gizi, antibiotik yang diberikan sebelumnya, dan diet sehari-hari sebagai faktor perancu. Sebagian besar populasi penelitian ini adalah anak berstatus gizi baik.
Hanya empat anak yang termasuk status gizi kurang. Tidak didapatkan perbedaan bermakna subjek pneumonia berat dan sangat berat dengan status gizi dan pemakaian antibiotik. Keadaan ini berarti bahwa status gizi dan pemakaian antibiotik tidak diikutsertakan dalam penilaian kadar seng plasma, karena tidak memengaruhi.

Pada penelitian ini terdapat perbedaan yang bermakna $(p=0,032)$ kadar seng plasma antara pneumonia berat dan sangat berat. Hal ini sesuai dengan penelitian oleh Shakur dkk. ${ }^{10}$ pada anak Banglades berstatus gizi baik yang menderita infeksi saluran napas bawah akut, dengan kadar seng plasma dan rambut yang signifikan $(p<0,05)$

Tabel 3 Kadar Seng Plasma pada Kelompok Pneumonia

\begin{tabular}{|c|c|c|c|}
\hline \multirow{2}{*}{$\begin{array}{c}\text { Kadar Seng Plasma } \\
(\mu \mathrm{g} / \mathrm{dL})\end{array}$} & \multicolumn{2}{|c|}{ Derajat Penyakit Pneumonia } & \multirow[b]{2}{*}{$\mathbf{p}$} \\
\hline & PB $(n=32)$ & PSB $(n=9)$ & \\
\hline $\begin{array}{l}\text { Rata-rata (SB) } \\
\text { Median } \\
\text { Rentang }\end{array}$ & $\begin{array}{c}103,047(31,994) \\
96,685 \\
57,32-195,66\end{array}$ & $\begin{array}{c}83,673(15,494) \\
80,240 \\
63,01-111,84\end{array}$ & $\begin{array}{c}\mathrm{Z}_{M W}=1,858^{*} \\
\mathrm{p}=0,032\end{array}$ \\
\hline $\begin{array}{l}\text { Tidak menurun } \\
\text { Menurun }(<80 \mu \mathrm{g} / \mathrm{dL})\end{array}$ & $\begin{array}{r}25 \\
7\end{array}$ & $\begin{array}{l}5 \\
4\end{array}$ & $\mathrm{p}=0,201 * *$ \\
\hline
\end{tabular}

Keterangan: *= uji Mann-Whitney, $\mathrm{PB}=$ pneumonia berat, $\mathrm{SB}=$ simpang baku, $\mathrm{PSB}=$ pneumonia sangat berat, $* *=$ uji eksak Fisher, bermakna bila $p<0,05$ 
lebih rendah dibandingkan dengan kontrol anak sehat. Hasil penelitian ini juga sesuai dengan penelitian Kumar dkk. ${ }^{11}$ di India Utara pada anak usia dua bulan sampai lima tahun yang dirawat dengan pneumonia berat, membuktikan bahwa kadar seng plasma penderita pneumonia signifikan lebih rendah $(\mathrm{p}=0,0003)$ dibandingkan dengan kontrol anak sehat.

Walaupun pada penelitian terdapat perbedaan bermakna kadar seng plasma antara kelompok pneumonia berat dan sangat berat, tetapi kadar rata-rata keduanya masih dalam batas normal, berturut-turut 103,047 dan 83,673 $\mu \mathrm{g} / \mathrm{dL}$. Hasil ini serupa dengan penelitian Shakur dkk. ${ }^{10}$ dan Kumar dkk. ${ }^{11}$ yang memperoleh hasil kadar seng plasma rata-rata pada infeksi saluran napas bawah dan pneumonia berat berturut-turut $90 \pm 51 \mu \mathrm{g} /$ $\mathrm{dL}$ dan $376,1 \pm 225,73 \mu \mathrm{g} / \mathrm{dL}$. Untuk mengetahui apakah hasil yang didapat pada penelitian ini masih merupakan bagian dari proses penurunan seng plasma yang terus terjadi, maka diperlukan penelitian lebih lanjut.

Batasan defisiensi seng dapat berbeda pada berbagai laboratorium dan penelitian, bergantung pada referensi yang dipergunakan. ${ }^{17}$ Batasan defisiensi kadar seng plasma yang digunakan pada penelitian ini adalah $<80 \mu \mathrm{g} / \mathrm{dL}$. Penurunan kadar seng plasma berdasarkan batasan yang ditetapkan hanya terjadi pada $11(26 \%)$ anak. Dalam penelitian Shakur dkk. ${ }^{10}$ batasan defisiensi seng plasma yang dipergunakan adalah $<100$ $\mu \mathrm{g} / \mathrm{dL}$. Hal ini menjadi salah satu alasan hanya terdapat $11(26 \%)$ anak mengalami penurunan kadar seng plasma. Selain itu, penelitian ini menggunakan metode cross-sectional dengan pemilihan subjek secara consecutive sampling, dan pengambilan sampel yang dilakukan sesuai dengan kedatangan penderita. Kadar seng plasma mencapai puncak variasi diurnal sekitar pukul 9.30 pagi. ${ }^{18}$ Waktu pengambilan sampel yang dilakukan pagi hari dapat memiliki hasil yang lebih tinggi dibandingkan dengan pengambilan sore atau malam hari, sehingga memengaruhi hasil pemeriksaan. Hasil dari kadar seng plasma juga sangat dipengaruhi oleh cara pengambilan, perlakuan, serta penyimpanan sampel sebelum dianalisis, yang merupakan langkah penting untuk mendapatkan hasil akurat. Sedikit kekurangan dalam penanganan sampel sejak pengambilan sampai analisis dapat turut serta memengaruhi hasil. ${ }^{18,19}$ Sarana pemeriksaan kadar seng plasma yang tersedia di laboratorium rumah sakit tempat penelitian berlangsung dapat meminimalkan perubahan kadar seng plasma yang terjadi, karena dapat segera dilakukan pemeriksaan. Persediaan seng tubuh sensitif terhadap jumlah seng yang diabsorpsi dari makanan, sehingga makanan yang dimakan subjek sangat memengaruhi kadar seng plasmanya. ${ }^{20}$

Kadar seng plasma yang turun pada pneumonia mungkin disebabkan sudah terjadi defisiensi seng sebelumnya. ${ }^{10}$ Defisiensi seng walaupun ringan dapat menekan sistem imun karena menyebabkan atrofi timus dan limfopenia. Seng memengaruhi sistem imun melalui perannya dalam maturasi limfosit, produksi sitokin, regulasi apoptosis dan ekspresi gen, serta sebagai antioksidan.,5

Berdasarkan ulasan Caulfield dan Black ${ }^{21}$ dari berbagai penelitian epidemiologi termasuk metaanalisis 11 penelitian intervensional, ditemukan bahwa defisiensi seng pada balita meningkatkan insidensi pneumonia. Berdasarkan hasil penelitian eksperimental acak terkontrol dibuktikan bahwa hubungan kadar seng plasma yang rendah dengan penyakit infeksi terjadi karena perubahan daya tahan pejamu, termasuk barier epitel dan respons imun..$^{22}$ Penelitian Sazawal dkk. ${ }^{23}$ dan Bhandari $\mathrm{dkk} \cdot{ }^{24}$ mengenai suplementasi seng, mengurangi morbiditas infeksi saluran napas bawah akut dan pneumonia. Pemberian seng sebagai terapi tambahan antimikrob standar pada anak 2-23 bulan dengan pneumonia berat, mengurangi durasi penyakit dan lama perawatan di rumah sakit. ${ }^{1}$

Walaupun jumlah subjek penelitian ini belum mencapai jumlah sampel minimal $(n=47)$, tetapi berdasarkan analisis data yang dilakukan telah didapatkan perbedaan yang bermakna kadar seng plasma pada subjek dengan pneumonia berat dan sangat berat, maka jumlah sampel yang didapat sudah mencukupi.

Keterbatasan pada penelitian ini yaitu tidak dilakukan pemeriksaan kadar seng plasma pada anak sehat, sehingga tidak diketahui perbandingan kadar seng plasma antara penderita pneumonia dan anak sehat. Waktu pengambilan sampel yang tidak seragam sehingga tidak dapat menghindari kadar puncak seng plasma sesuai variasi diurnal. Keterbatasan lain penelitian ini yaitu kesulitan meniadakan faktor perancu. yaitu diet sehari-hari subjek penelitian yang dapat memengaruhi kadar seng plasma yang sensitif terhadap jumlah seng yang diabsorpsi dari makanan. ${ }^{20}$

Simpulan, kadar seng plasma mempunyai hubungan dengan pneumonia berat dan sangat berat pada anak usia 2-59 bulan.

\section{Daftar Pustaka}

1. Brooks WA, Yunus M, Santosham M, Wahed MA, Nahar K, Yeasmin S, dkk. Zinc for severe pneumonia in very young children: double-blind placebo controlled trial. Lancet. 2004;363(9422):1683-8.

2. Departemen Kesehatan Republik Indonesia. Profil kesehatan Indonesia 2007. Jakarta: 
Depkes RI; 2007.

3. Buku saku pelayanan kesehatan anak di rumah sakit. Pedoman bagi rumah sakit rujukan tingkat pertama di kabupaten/kota. Jakarta: WHO Indonesia; 2008.

4. Fraker PJ, King LE, Laakko T, Vollmer TL. The dynamic link between the integrity of the immune system and zinc status. J Nutr. 2000;130 (5S Suppl):1399-406S.

5. Field CJ, Johnson IR, Schley PD. Nutrients and their role in host resistance to infection. $\mathrm{J}$ Leukoc Biol. 2002;71(1):16-32.

6. Thu BD, Schultink W, Dillon D, Gross R, Leswara ND, Khoi HH. Effect of daily and weekly micronutrient supplementation on micronutrient deficiencies and growth in young Vietmanese children. Am J Clin Nutr. 1999;69(1):80-6.

7. Ugwija EI, Nwosu KO, Ugwu NC, Okonji M. Serum zinc and copper levels in malnourished pre-school age children in Jos, North Central Nigeria. Pakistan J Nutrit. 2007;6(4):349-54.

8. Lomaestro BM, Bailie GR. Absorption interactions with fluoroguinolones. 1995 update. Drug Saf. 1995;12(5):314-33.

9. Penttila O, Hurme H, Neuvonen PJ. Effect of zinc sulphate on the absorption of tetracycline and doxycyline in man. Eur $\mathbf{J}$ Clin Pharmacol. 1975;9(2-3):131-4.

10. Shakur MS, Malek MA, Bano N, Islam K. Zinc status in well nourished Bangladeshi children suffering from acute lower respiratory infection. Indian Pediatr. 2004;41(5):478-81.

11. Kumar S, Awasthi S, Jain A, Srivastava RC. Blood zinc levels in children hospitalized with severe pneumonia: a case control study. Indian Pediatr. 2004;41(5):486-91.

12. Sectish TC, Prober CG. Pneumonia. Dalam: Kliegman RM, Behrman RE, Jenson HB, Stanton BF, penyunting. Nelson textbook of pediatrics. Edisi ke-18. Philadelphia: Saunders Elsevier; 2007. hlm. 1795-800.

13. Bose A, Coles CL, Gunavathi, John H, Moses P, Raghupathy P, dkk. Efficacy of zinc in the treatment of severe pneumonia in hospitalized children $<2$ y old. Am J Clin Nutr. 2006;83(5):1089-96.

14. Scott JAG. The global epidemiology of childhood pneumonia 20 years on. Bull World Health Organ. 2008;86(6):494-6.

15. Khan AJ, Hussain H, Omer SB, Chaudry S, Ali S, Khan A, dkk. High incidence of childhood pneumonia at high altitudes in Pakistan: a longitudinal cohort study. Bull World Health Organ. 2009;87:193-9.

16. Crowe JE. Viral pneumonia. Dalam: Chernick, Boat TF, Wilmott RW, Bush A, penyunting. Kendig's disorders of the respiratory tract in children. Philadelphia: Saunders Elsevier; 2006. hlm. 433-40.

17. Shenkin A, Baines M, Fell GS, Lyon TDG. Vitamins and trace elements. Dalam: Burtis CA, Ashwood ER, Bruns DE, penyunting. Tietz textbook of clinical chemistriy and molecular diagnostics. Edisi ke-4. Missouri: Elsevier Saunders; 2006. hlm. 1137-64.

18. Eby GA. Handbook for curing the common cold the zinc lozenge story. Texas: George Eby Research; 1994.

19. Frank EL, Hughes MP, Bankson DD, Roberts WL. Effects of anticoagulants and contemporary blood collection containers on alumunium, copper, and zinc results. Clin Chem. 2001;47(6):1109-12.

20. Almatsier S. Mineral mikro: prinsip dasar ilmu gizi. Edisi ke-1. Jakarta: PT. Gramedia Pustaka Utama; 2001.

21. Caulfield LE, Black RE. Zinc deficiency. [diunduh 11 Mar 2009]. Tersedia dari: http:// www.who.int/publications/cra/chapters/ volume1/0257-0280.pdf.

22. Black RE. Zinc deficiency, immune function, and morbidity and mortality from infectious disease among children in developing countries. Food Nutr Bull. 2001;22(2):15562.

23. Sazawal S, Black RE, Jalla S, Mazumdar S, Sinha A, Bhan MK. Zinc supplementation reduces the incidence of acute lower respiratory infection in infants and preschool children: a double-blind, controlled trial. Pediatrics. 1998;102(1 Pt 1):1-5.

24. Bhandari N, Bahl R, Taneja S, Strand T, Molbak K, Ulvik RJ, dkk. Effect of routine zinc supplementation on pneumonia in children aged 6 months to 3 years: randomised controlled trial in an urban slum. BMJ. 2002;324(7350):1358-62. 